\title{
Using Porous Media to Improve the Performance of a Wavy-tube Heat Exchanger
}

\section{Arash Soltani-Tehrani}

MSc Student

Department of Mechanical Engineering Isfahan University of Technology

Isfahan,

Mohammad Reza Tavakoli

Assistant Professor

Department of Mechanical Engineering Isfahan University of Technology

Isfahan,

Iran

Mohammad Reza Salimpour

Professor

Department of Mechanical Engineering Isfahan University of Technology Isfahan,
Heat transfer increase has been always the industries' aim. One of the methods to increase heat transfer is to manufacture heat exchangers with specific geometries such as wavy-tube heat exchangers. In this study, effects of inserting homogenous porous media to amplitudes of a wavy-tube heat exchanger have been investigated. A pipe with a length of $4 \lambda(\lambda$ is the wavelength) was considered. Surface waviness has been introduced by $L^{*}$, which is the ratio of wavelength to half of the amplitude. The computations were repeated for three different $L *$ values including 11,19 and 25 . Effects of surface waviness and porous media properties including porosity and Darcy number on the heat transfer and pressure drop for a fully-developed laminar flow are provided. Results show that using porous media will lead to both heat transfer and pressure drop increase. The heat exchanger's efficieny was measured by Performance Evaluation Criteria (PEC) which is the ratio of heat transfer increase to pressure drop increase. It was observed that for $10^{-6} \leq D a \leq 10^{-4}$, filling the amplitudes out with porous media with thicknesses less than the amplitude will result in the maximum $P E C$ while for $10^{-4} \leq D a \leq 10^{-2}$, filling out thoroughly will result in the maximum PEC. In addition, it was found that there is an optimized porosity to have the maximum PEC for the constant Darcy number.

Keywords: Porous media; Wavy-tube heat exchangers; Sinusoidal heat exchangers; Forced convection; Local Thermal Equilibrium model

\section{INTRODUCTION}

Heat exchangers are used for energy transfer between two or more fluids, one fluid and one solid surface, or solid particles and a fluid in different temperatures. Heat exchangers may be used in a wide range of applications such as cooling, heating, evaporating, distillation, pasteurizing, and crystalizing. They can be used separately or as a part of a larger heating systems for domestic, commercial or industrial purposes. They can be categorized to different groups with different considerations. Bergles [1] categorized heat transfer increasing methods to two main groups: active and passive. Active methods are the ones which use an external force. However, in passive methods, there is not such a force such as wavy tubes and porous media. Porous media is defined with two characteristics: Porosity $(\phi)$, the ratio of vacant spaces to the total volume of porous medium and Permeability $(K)$, the ability of passing fluid in porous media.

Wang and Chen [2] with numerical solution reported that with increasing the ratio of amplitude to wave length, the local Nusselt number would increase extremely in the converged section, but there was a slight change in concaved section. Mahmud et Al. [3] studied the effect of corrugation on flow pattern, wall stress, pressure drop and heat transfer in a tube. In their

Received: November 2017, Accepted: June 2018

Correspondence to: Mohammad Reza Tavakoli

Assisstant Professor, Department of Mechanical Engineering, Isfahan Universtity of technology, Iran

E-mail:mrtavak@cc.iut.ac.ir

doi:10.5937/fmet1804631S

(C) Faculty of Mechanical Engineering, Belgrade. All rights reserved study, a tube with length of $4 \lambda$ was considered in a laminar flow $(50 \leq R e \leq 2000)$ using finite-volume method. They have shown that the friction factor has an indirect correlation with Reynolds numbers defined as $f=\frac{C}{R e^{m}}$, in which $C$ and $m$ are constants.

Kanna et al. numerically studied the forced convection heat transfer from two square cylinders in a channel covered by solid walls [4]. Upstream and downstream cylinders showed higher Nusselt numbers during steady state and for the periodic flow, respectively. It was observed that the average Nusselt number increases with the Reynolds number increase.

\section{GOVERNING EQUATIONS}

The geometry of the problem is shown in Figure 1. As it is shown, $r$ is the tube's radius, $D_{\max }$ is the maximum diameter of the wavy tube and $D_{\min }$ is the minimum one, $\lambda$ is the wavelength, $U_{0}$ is the inlet velocity, $H_{\text {porous }}$ is the thickness of inserted porous media and $a$ is half of the amplitude. The distance from the inlet in line with the tube axis is $x$. Also, $X$ is the dimensionless ratio of the $x$ to the wavelength. According to Figure 1, $r$ is computed via (1) [3].

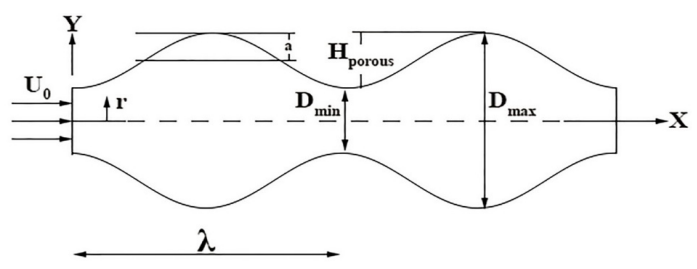

Figure 1. The geometry of a wavy-tube heat exchanger 


$$
r=\frac{D_{\min }}{2}+a\left[a-\sin \left(\frac{\pi}{2}\left(1+\frac{4 x}{\lambda}\right)\right)\right]
$$

Shape parameter $\left(L^{*}\right)$ is defined by (2) [3].

$$
L^{*}=\frac{\lambda}{a}
$$

In which, $\lambda$ is the wavelength and $a$ is half of the amplitude, which is defined by (3) [3]:

$$
a=\frac{D_{\max }-D_{\min }}{4}
$$

Boundary conditions are:

$$
\begin{gathered}
X=0 \rightarrow v=0, T=T_{i n}, u=U_{0} \\
X=4 \rightarrow P=P_{a t m} \\
0 \leq X \leq 4, r=\frac{D_{\min }}{2}+a\left[1-\sin \left(\frac{\pi}{2}(1+4 X)\right)\right] \rightarrow \\
\rightarrow u=v=0, T=T_{\text {wall }} \\
0 \leq X \leq 4, r=0 \rightarrow \frac{\partial u}{\partial r}=\frac{\partial v}{\partial r}=\frac{\partial T}{\partial r}=0 \\
X=4,0 \leq r \leq \frac{D_{\min }}{2} \rightarrow \frac{\partial u}{\partial x}=\frac{\partial v}{\partial x}=\frac{\partial T}{\partial x}=0
\end{gathered}
$$

The present study is conducted for three different $L^{*}$ including 11, 19 and 25. In all cases, wavelength $(\lambda)$ and minimum diameter $\left(D_{\min }\right)$ are considered respectively 10 $\mathrm{cm}$ and $4.02 \mathrm{~cm}$. With these parameters and according to (2) and (3), $a$ and $D_{\max }$ are obtained. Continuum and Momentum equations for a steady-state, laminar, and incompressible flow are respectively [5]:

$$
\begin{aligned}
& \frac{\partial(\rho u)}{\partial x}+\frac{1}{r} \frac{\partial(r \rho v)}{\partial r}=0 \\
& \frac{\partial(\rho u u)}{\partial x}+\frac{1}{r^{n}} \frac{\partial\left(r^{n} \rho u u\right)}{\partial r}=-\frac{\partial P}{\partial x}+\frac{\partial\left(\mu \frac{\partial u}{\partial x}\right)}{\partial x}+ \\
& \frac{1}{r^{n}} \frac{\partial\left(r^{n} \mu \frac{\partial u}{\partial r}\right)}{\partial r}-j \frac{\mu u}{K}-j \frac{\rho F}{\sqrt{K}}|u| u \\
& \frac{\partial(\rho u v)}{\partial x}+\frac{1}{r^{n}} \frac{\partial\left(r^{n} \rho u v\right)}{\partial r}=-\frac{\partial P}{\partial x}+\frac{\partial\left(\mu \frac{\partial v}{\partial x}\right)}{\partial x}+ \\
& \frac{1}{r^{n}} \frac{\partial\left(r^{n} \mu \frac{\partial v}{\partial r}\right)}{\partial r}-j \frac{\mu v}{K}-j \frac{\rho F}{\sqrt{K}}|u| v-\frac{\mu v}{r^{2}}
\end{aligned}
$$

In (10) and (11), $j=1$ for porous media, and $j=0$ when there is not porous media. In addition, for a pipe, $n=1$ and $\mathrm{n}=0$ for a channel. $F$ is the geometric function based on the experimental results [6]. Energy equations outside and inside of the porous media are respectively [5]:

$$
\frac{\partial\left(\rho u C_{\mathrm{p}} T\right)}{\partial x}+\frac{1}{r} \frac{\partial\left(r \rho C_{\mathrm{p}} v T\right)}{\partial r}=\frac{\partial\left(k_{\mathrm{f}} \frac{\partial T}{\partial x}\right)}{\partial x}+\frac{1}{r} \frac{\partial\left(r k_{\mathrm{f}} \frac{\partial T}{\partial r}\right)}{\partial r}
$$

$$
\begin{gathered}
\frac{\partial\left(\rho u C_{\mathrm{p}} T\right)}{\partial x}+\frac{1}{r} \frac{\partial\left(r \rho C_{\mathrm{p}} v T\right)}{\partial r}= \\
=\frac{\partial\left(k_{\mathrm{eff}} \frac{\partial T}{\partial x}\right)}{\partial x}+\frac{1}{r} \frac{\partial\left(r k_{\mathrm{eff}} \frac{\partial T}{\partial r}\right)}{\partial r}
\end{gathered}
$$

In which, $p$ and $f$ are respectively representatives for porous media and fluid. $k_{\text {eff }}$ is the efficient thermal conductivity and is defined by (13) [5].

$$
k_{\text {eff }}=(1-\phi) k_{\mathrm{p}}+\phi k_{\mathrm{f}}
$$

$\phi$ is the porosity of porous media. Also, for a Local Thermal Equilibrium condition [7]:

$$
1<t k r=\frac{k_{e f f}}{k_{\mathrm{f}}}<10
$$

Another important porous media parameter is the permeability. To investigate permeability effects, Darcy number is defined (15) [5].

$$
D a=\frac{K}{d^{2}}
$$

$K$ is the permeability of porous media and $d$ is the characteristic length. Darcy parameter is dimensionless. Viscous Resistance is defined by (16).

$$
\text { Viscous resistance }=\frac{1}{K}=\frac{1}{D a \times D_{\mathrm{h}}^{2}}
$$

In which $D_{\mathrm{h}}$ is the hydraulic diameter defined by (17):

$$
D_{\mathrm{h}}=\frac{D_{\max }+D_{\min }}{2}
$$

To compare a void wavy tube with the one with porous media, (18) was used to assess the overall performance of the heat exchanger [8].

$$
P E C=\frac{\frac{N u}{N u_{\mathrm{s}}}}{\left(\frac{f}{f_{\mathrm{s}}}\right)^{1 / 3}}
$$

In which $N u$ and $f$ are for the wavy tube with porous media, and $N u_{\mathrm{s}}$ and $f_{\mathrm{s}}$ are representatives for the void wavy tube. The critical value for $P E C$ is 1 , and the more the $P E C$ value, the more the heat exchanger's efficiency is.

\section{VALIDATIONS}

To validate the present study, the local Nusselt number over the tube length was measured by (19).

$$
N u(x)=\frac{D_{\mathrm{h}}}{T_{\mathrm{w}}-T_{\mathrm{b}}} \times\left(\frac{\partial T}{\partial n}\right)_{\text {wall }}
$$

In this equation, $T_{\mathrm{w}}$ and $T_{\mathrm{b}}$ are respectively the wavy-tube wall and bulk temperatures. Also, $\left(\frac{\partial T}{\partial n}\right)_{\text {wall }}$ 
shows the temperature gradient in the direction normal to wavy-tube wall. For $L^{*}=19$ and $R e=300$, local Nusselt number is shown in Figure 2, presenting a good conformity with [3].

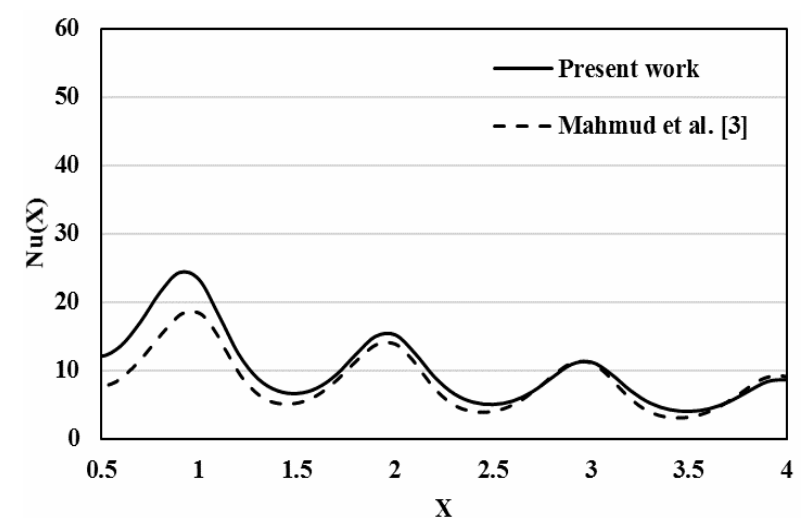

Figure 2. Local Nusselt number of the present work and Mahmud et al. [3]

\section{RESULTS AND DISCUSSION}

To investigate permeability effects, different Darcy numbers from $10^{-6}$ to $10^{-2}$ were considered [5]. Figure 3 to Figure 6 are shown for Darcy numbers respectively $10^{-6}, 10^{-5}, 10^{-4}, 10^{-3}, 10^{-2}, L^{*}=19$ and $R e=300$.

By considering Figure 3 to Figure 6, it is evident that for $10^{-6} \leq D a \leq 10^{-4}$, maximum $P E C$ value will occur in thicknesses less than the amplitude. But, for $10^{-4} \leq D a \leq$ $10^{-2}$, this value is exactly equal to the amplitude. These tests were repeated for $L^{*}=11$ and 25 , and the results were the same. In Figure 7, all optimized thicknesses values leading to maximum $P E C$ values are shown. It is obvious that for $10^{-4} \leq D a$ the optimum amount leading to the maximum $P E C$ value is $100 \%$. However, for $10^{-4}$ $>D a$, the optimized amount is less than $100 \%$. This amount will increase for smaller $L^{*}$ numbers (more waviness), and this is because of more heat transfer in wavy tubes with larger amplitudes. The transition in $D a$ $=10^{-4}$ for all different $L^{*}$ numbers is because of that in these regions, larger Darcy numbers will lead to less viscous resistance and more heat transfer, and heat transfer is more dominant in such regions. Figure 7 can be used for all different $L^{*}$ numbers between $11-25$ to predict the behavior of wavy tubes.

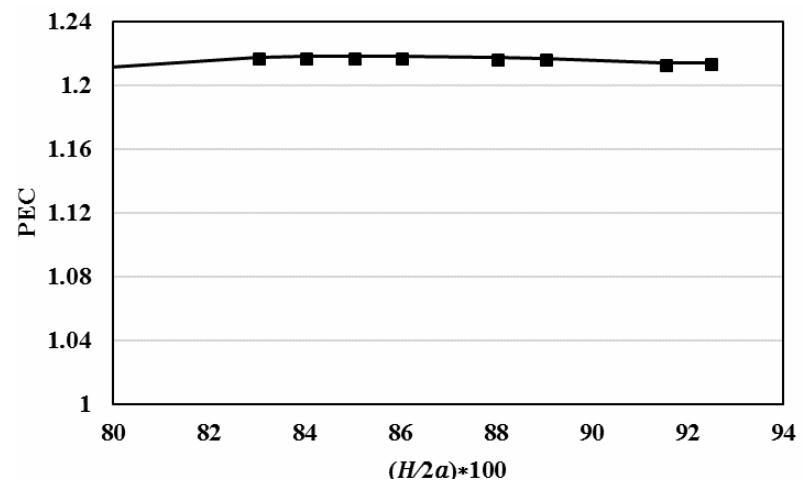

Figure 3. $P E C$ for $D a=10^{-6}, L^{*}=19$ and $R e=300$

For investigating porosity, all the parameters were considered constant except porosity in a specific Darcy number $\left(D a=10^{-4}\right)$. In Figure 8 , it is evident that by decreasing the porosity, $P E C$ value increased and after a specific porosity (here 0.84 ), it decreased again.

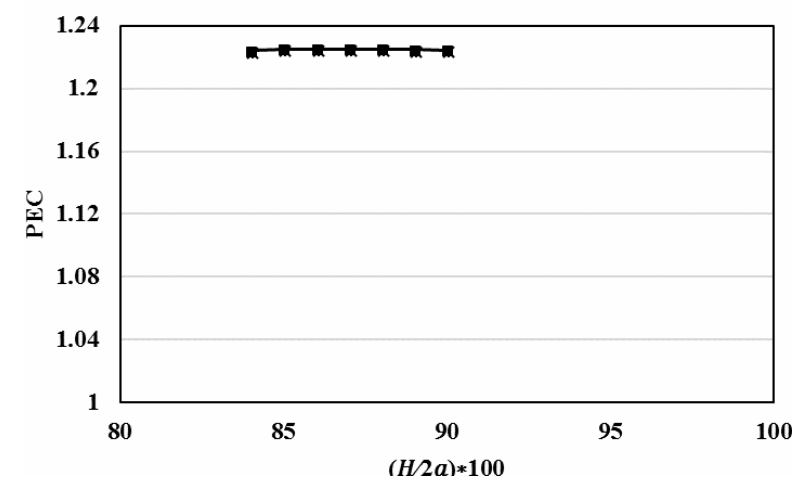

Figure 4. $P E C$ for $D a=10^{-5}, L^{*}=19$ and $R e=300$

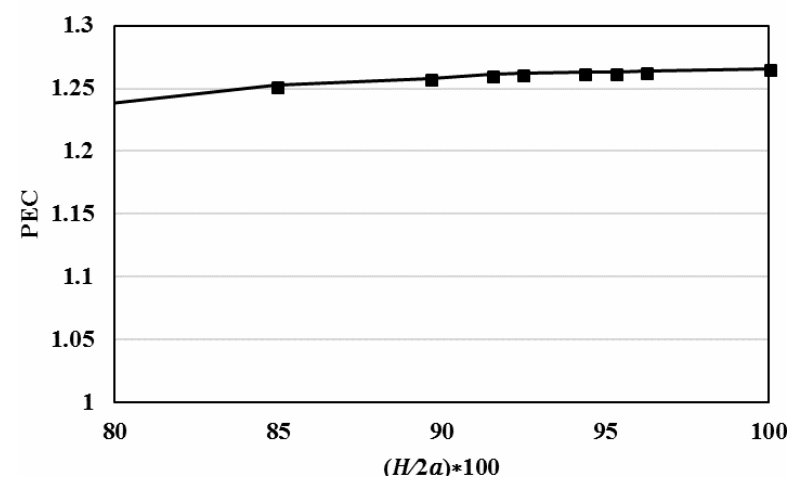

Figure 5. PEC for $\mathrm{Da}=10^{-4}, L^{*}=19$ and $R e=300$

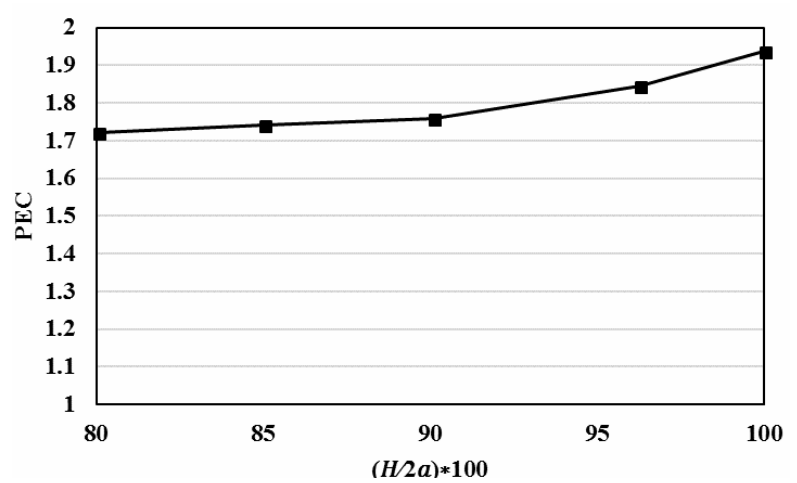

Figure 6. $P E C$ for $D a=10^{-3}, L^{*}=19$ and $R e=300$

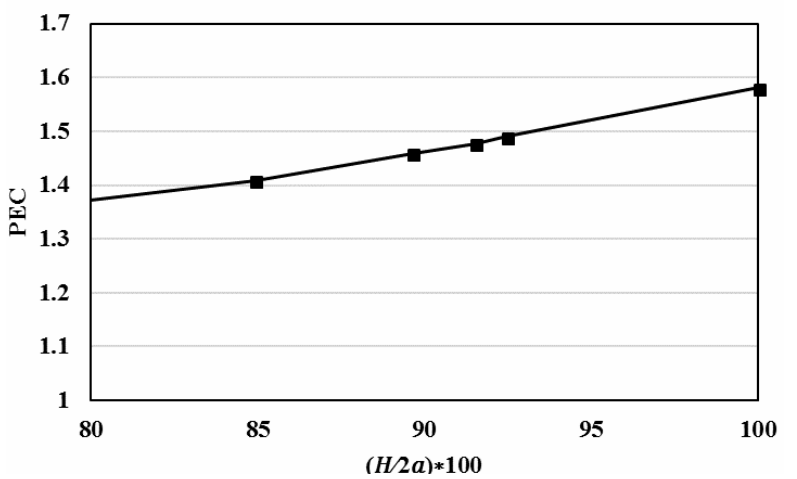

Figure 6. $P E C$ for $D a=10^{-2}, L^{*}=19$ and $R e=300$

Hence, when using porous media, it is important to choose the optimized porosity to have the maximum efficiency. In addition, by decreasing the porosity, heat transfer was increased while the pressure drop remained constant, and this is because by decreasing the porosity, 
the vacant places will be decreased. Hence, there will be more solid material which has a more thermal conductivity.

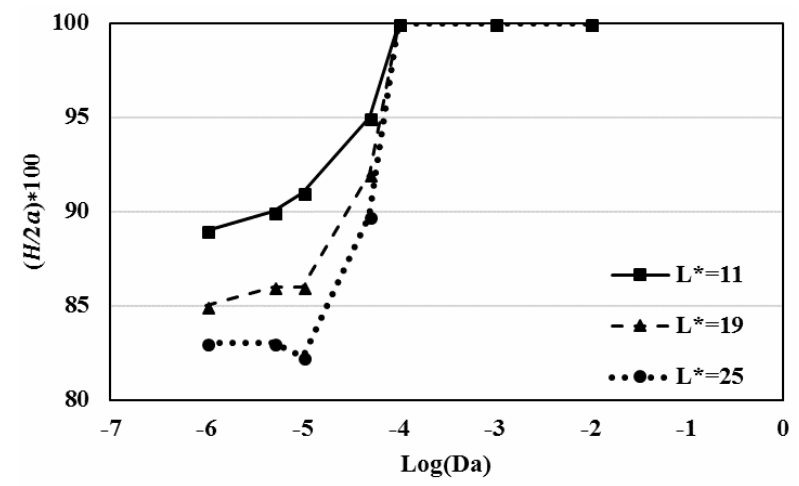

Figure 7. Optimized thickness of porous media for $L^{*}=11,19$ and 25

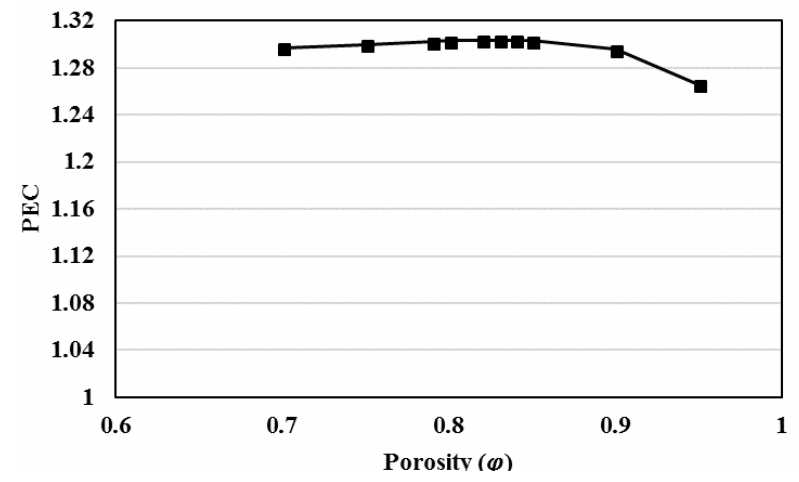

Figure 8. $P E C$ values for different porosities for $D a=10^{-4}$

\section{CONCLUSION}

In the present study, a wavy-tube heat exchanger was considered. Previous researches have been done to investigated the heat transfer in wavy tubes, and it was seen that it will lead to heat transfer increase. In the present work, porous media was inserted into the amplitudes of the wavy tube with different Darcy numbers and porosities to analyze the behavior, heat transfer, and pressure drop in the tube.

It was seen that in all cases, heat transfer and pressure drop will increase. However, to see the effects of both heat transfer and pressure drop simultaneously, $P E C$ value which relates heat transfer to pressure drop was calculated for each Darcy number individually.

It was shown that for $10^{-4} \leq D a$, when the wavy tube's amplitude is completely filled with porous media, maximum $P E C$ value will be obtained. However, for $10^{-}$ $4>D a$, maximum $P E C$ value was resulted in thicknesses less than the wavy tube's amplitude.

This study was repeated for $L^{*}=11$ and 25 and same results occurred. Therefore, when using porous media to improve the heat transfer efficiency, different porous media properties like Darcy number and porosity should be considered to have the maximum efficiency.

\section{REFERENCES}

[1] Bergles, A.E.: The implications and challenges of enhanced heat transfer for the chemical process industries, Chemical Engineering Research and Design, Vol. 79, No. 4, pp. 437-444, 2001.

[2] Wang, C.C., Chen, C.K.: Forced convection in a wavy-wall channel, International Journal of Heat and Mass Transfer, Vol.45, No.12, pp. 2587-2595, 2002.

[3] Mahmud, S., Islam, A.S. and Feroz, C.: Flow and heat transfer characteristics inside a wavy tube, Heat and mass transfer, Vol. 39, No. 5-6, pp. 387393, 2003.

[4] Kanna, R.P., Sivasubramanian, M. and Uthayakumar, M.: Numerical investigation of forced convection heat transfer from square cylinders in a channel covered by solid wall: Conjugate situation, FME Transactions, Vol. 45, No. 1, pp. 16-25, 2017.

[5] Nield, D.A., Bejan, A.: Convection in porous media, in: New York: springer, pp. 566-631, 2006.

[6] Amiri, A., Vafai, K.: Analysis of dispersion effects and non-thermal equilibrium, non-Darcian, variable porosity incompressible flow through porous media, International Journal of Heat and Mass Transfer, Vol. 37, No. 6, pp. 939-954, 1994.

[7] Teamah, M.A., El-Maghlany, W.M. and Dawood, M.M.K.: Numerical simulation of laminar forced convection in horizontal pipe partially or completely filled with porous material, International Journal of Thermal Sciences, Vol. 50, No. 8, pp. 1512-1522, 2011.

[8] Khan, T.A., Li, W.: Numerical study on the performance of a tube with inserted porous media of various thermal conductivities, in: ASME 2016 Heat Transfer Summer Conference collocated with the ASME 2016 Fluids Engineering Division Summer Meeting and the ASME $201614^{\text {th }}$ International Conference on Nanochannels, Microchannels, and Minichannels, 10-14.07.2016, Washington, pp. V001T01A008-V001T01A008.

\section{NOMENCLATURE}

$\mathrm{Nu} \quad$ Nusselt Number

$P \quad$ Pressure, $\mathrm{Pa}$

$U \quad$ Velocity, $\mathrm{m} / \mathrm{s}$

$D \quad$ Diameter, $\mathrm{cm}$

$H \quad$ Thickness, cm

$k \quad$ Thermal Conductivity, W/(m.K)

$K \quad$ Permeability, $\mathrm{m}^{2}$

$L \quad$ Length, cm

$T \quad$ Temperature, $\mathrm{K}$

$a \quad$ Half of the amplitude, $\mathrm{cm}$

$f \quad$ Friction factor

Re Reynolds number

$N u \quad$ Nusselt number for the void wavy-tube heat exchanger

$f_{\mathrm{s}} \quad$ Friction factor for the void wavy-tube heat

exchanger

$P E C$ overall performance of the heat exchanger

$\mathrm{Da} \quad$ Darcy number

$u, v \quad$ Velocity components, $\mathrm{m} / \mathrm{s}$

$C_{P} \quad$ Heat capacity, $\mathrm{Kg} . \mathrm{m}^{2} / \mathrm{K} . \mathrm{s}^{2}$ 


\section{Greek symbols}

$$
\begin{array}{cl}
\rho & \text { Density, Kg/m } \mathrm{m}^{3} \\
\mu & \text { Viscosity, Pa.s } \\
\phi & \text { Porosity } \\
\lambda & \text { Wavelength, cm }
\end{array}
$$

\section{КОРИШЋЕЊЕ ПОРОЗНИХ МЕДИЈА ЗА \\ ПОБОЉШАЊЕ ПЕРФОРМАНСИ ИЗМЕЊИВАЧА ТОПЛОТЕ СА ТАЛАСАСТИМ ЦЕВИМА}

\section{А. Солатани-Техрани, М. Р. Таваколи, М. Р. Салимпур}

Индустрија је од увек имала за циљ повећање преноса топлота. Један од начина да се оствари поменути циљ је производња измењивача топлоте специфичне геометрије као што су нпр. таласасте цеви. Рад истражује ефекте уметања хомогених порозних медија у амплитуду измењивача топлоте са таласастим цевима. Разматра се цев дужине $4 \lambda$ ( $\lambda$ је таласна дужина). Површинска таласастост је уведена помоћу L* које представља однос таласне дужине и половине амплитуде. Израчунавања су поновљена три пута за три различите вредности $\mathrm{L}^{*}$ : 11,19 и 25. Приказан је утицај површинске таласастости и својства порозности медија, укључујући порозност и Дарсијев број, на пренос топлоте и пад притиска код потпуно развијеног ламинарног струјања. Резултати показују да примена порозних медија доводи до повећања преноса топлоте и пада притиска. Степен искоришћења измењивача топлоте је измерен применом критеријума за евалуацију перформанси, што представља однос између повећања преноса топлоте и повећања пада притиска. Утврђено је да за $10^{-6} \leq \mathrm{Da} \leq 10^{-4}$ попуњавање амплитуда порозним медијумом чија је дебљина мања од амплитуде доводи до максималне вредности перформанси, док за $10^{-4} \leq \mathrm{Da} \leq 10^{-2}$ потпуна испуњеност амплитуде доводи до максималне вредности перформанси. Осим тога, утврђено је да постоји оптимизирана порозност за максималну вредност перформанси са константним Дарсијевим бројем. 